\title{
Planning as the basis of strategic development of the construction organization
}

\author{
Pavel Oleinik ${ }^{1, *}$ \\ ${ }^{1}$ Moscow State University of Civil Engineering, 129337, 26, Yaroslavskoye Shosse, Moscow, Russia
}

\begin{abstract}
A unified planning system for construction production is considered, including interconnected planning levels - general, strategic, current, operational. A planning period, a list of tasks to be solved and features of their solution are presented for each level. The statement of the problem of determining capital investments for the development of means of production is disclosed and the relationship between the indicators of finished construction products and means of production is described. The procedure for transforming the model for determining capital investments and reducing its solution to a homogeneous linear equation in finite differences is described.
\end{abstract}

\section{Introduction}

Planning is the most important function of construction management. During the implementation of planning the strategy for the construction organization for the near future is formed, the development of means of production is forecasted, the organizational structure of the units and management apparatus, the management system and quality control of construction products are adjusted.

The main provisions of the planning system are aimed at achieving economic efficiency and targeted decisions, balance and continuity of the planning stages, consideration of market conditions and external factors.

\section{Materials and methods}

In the early years of the transition to market relations, the role of planning in construction was in some way lost, since the whole system of centralized management of the construction industry was actively collapsing at both the federal and regional levels.

Now, construction organizations had to independently solve the whole range of tasks of their own development, including the search for contract work volumes and the search for financial and means of production. As a result, some construction companies have successfully entrenched in the construction market, while others have fallen of a radar [3].

The transition of the country's economy to state and private ownership has qualitatively increased the degree of responsibility of construction organizations. However, a significant deficit of own funds and high rates of bank loans, as well as increasing defaults and the presence of a

\footnotetext{
*Corresponding author: aljurgaitis@gmail.com
} 
large share of worn-out equipment forced construction organizations to seek out and use inefficient reserves of construction production, which undoubtedly have negatively affected the quality of construction products. In particular, for example, the increase in manual labor at construction sites sharply reduced the overall organizational and technological level of construction and significantly reduced the volume of application of progressive methods and forms of organizing the construction and construction works. In this regard, construction organizations gradually began to return to the need to use planning as a stage in determining their strategy and activity priorities, developing marketing services and predicting consolidation in the construction market. A new quality of planning tasks, the solution of which is now aimed at increasing share capital and increasing net profit, is formed under the influence of increasing requirements for the management of investment and construction projects and the intensive development of information modeling technologies $[4,5]$.

As the experience of a number of successfully developing construction organizations shows, a planning system can be considered effective if it considers the entire process of its origin, preparation and implementation. Therefore, the planning system in the form of its interconnected following levels - general, strategic, current and operational is the most successful in modern conditions (Table 1).

Table 1. Main objectives of construction planning.

\begin{tabular}{|c|c|c|c|}
\hline No. & Planning level & $\begin{array}{c}\text { Planning period } \\
\text { (year) }\end{array}$ & Main objectives \\
\hline \multirow[t]{3}{*}{ I } & \multirow[t]{3}{*}{ General } & \multirow[t]{3}{*}{$5-7$} & $\begin{array}{l}\text { Cost: } \\
\text { stock price growth; increase in net profit; retention and } \\
\text { expansion of market share; increase in dividend payout; } \\
\text { cost reduction; pay increase. }\end{array}$ \\
\hline & & & $\begin{array}{l}\text { Material: } \\
\text { growth in finished construction products; improvement of } \\
\text { quality of construction products; growth in sales and } \\
\text { services for construction, reconstruction and overhaul; } \\
\text { strengthening the survival of the organization. }\end{array}$ \\
\hline & & & $\begin{array}{l}\text { Social: } \\
\text { improvement of working conditions; expansion of the } \\
\text { package of social support for employees; strengthening } \\
\text { of the image of the organization; maintaining of relations } \\
\text { with local and federal authorities. }\end{array}$ \\
\hline II & Strategic & $3-4$ & $\begin{array}{l}\text { Development (adjustment) of the development strategy } \\
\text { and program; determination of the nomenclature and } \\
\text { volumes of development of the means of production; } \\
\text { adjustment of basic management structures and } \\
\text { construction and installation works; adaptation of the } \\
\text { management system; optimization of the quality control } \\
\text { system of construction products; acquisition (adjustment) } \\
\text { of the regulatory and methodological base. }\end{array}$ \\
\hline
\end{tabular}




\begin{tabular}{|l|l|l|l|}
\hline III & Current & & \multicolumn{1}{|c|}{$\begin{array}{l}\text { Construction production plan (including documentation } \\
\text { on the organization of work); } \\
\text { work plan for auxiliary production facilities; } \\
\text { design work plan; } \\
\text { plan for the technical development of production and } \\
\text { own capital investments; } \\
\text { work plan; } \\
\text { mechanization plan; } \\
\text { logistics plan; } \\
\text { profit plan; } \\
\text { labor protection action plan; } \\
\text { action plan for environmental protection and rational use } \\
\text { of natural resources; } \\
\text { overhead estimate; } \\
\text { balance of income and expenses. }\end{array}$} \\
\hline IV & Operational & $\begin{array}{l}\text { Construction and installation work plan for own forces; } \\
\text { construction and installation works plan for } \\
\text { subcontracting organizations; } \\
\text { delivery plan for basic building materials, structures and } \\
\text { equipment; } \\
\text { mechanization plan; } \\
\text { occupational support plan; } \\
\text { freight plan; } \\
\text { cost plan. }\end{array}$ \\
\hline
\end{tabular}

General planning belongs to the category of long-term planning and its task is to determine the final results of the activities of the construction organization for a 5-7 year period of time. Therefore, the total indicators are divided into cost, material and social indicators. The priority task in terms of cost is to increase the cost of the construction organization as the most objective assessment of its successful development. For this purpose a forecast of the potential cost of equity, based on a full analysis of the assets, is developed, which in turn is the fundamental basis for determining the share of net profit, the possibility of expanding the sales market, and increasing the wages of workers. It should also be noted that the forecast of growth in the cost of a construction organization determines material and social indicators, which are derived from the level of change in the effectiveness of the construction organization.

Strategic planning is principally the approval of the main directions of development of the construction organization for the next 3-4 years with a set of measures for sustainability and competitiveness. Sustainability indicators are the stability of the volume of work, the rational structure of production units and governing bodies, an effective system of management and quality control of construction products. To maintain competitiveness, modern means of production are acquired, and the professional qualification and number of grassroots divisions and governing bodies are adjusted. As a rule, the worked out strategy of the construction organization's activities is enshrined in the development program, which provides for the name of the activities, the amount of allocated financial and other resources, deadlines and specific responsible executors. At the same time, options for its possible adjustment to cases of significant influence of external and internal factors are attached to the main strategy.

The most developed level of planning is current planning, which is advisable to be developed for a two-year period. As domestic experience shows, the result of current planning is a production and economic program that includes 12 sections that reflect all aspects of the production, technical, economic and social activities of a construction organization. The central section is the "Construction Production Plan", which contains tasks for the execution of construction contracts and the provision of services with the customers and contractors for two years, taking into account the transition from the backlog of the first year to the second. If the 
production plan for the second year is not secured by contracts, then it shall remain open for replenishment within the remaining capacity of the construction organization. For the next year, the plan of the second year becomes the plan of the current year, and this cycle shall be repeated continuously $[5,7]$.

A special role in the current planning is given to documentation on the organization of work for the annual (two-year) production program of the construction organization. Such documentation usually includes a consolidated annual (two-year) schedule for the construction of facilities included in the production program, as well as schedules for the development and issuance of project documentation, staffing requirements, work of the main building machines and mechanisms, requirements and supply of building materials, structures and equipment. The full coordination of the planned volumes of work of the annual production program with the capacities of the general contracting construction organization and the subcontracting organizations attracted by it are carried out at this stage.

The final level and integral component of a unified planning system is operational planning, which includes a set of operational plans for all areas of work, which are equal to the plan of the construction organization in the amount of relevant indicators. The basis of such operational plans is the formation of daily and weekly schedules that determine the volume of work performed by own forces and by subcontracting organizations in physical terms and estimated cost, the sequence and volume of supplies of materials, structures, equipment and construction machines and mechanisms, the allocation of workers for implementation monthly plans in accordance with the approved consolidated annual calendar plan.

Among the most important tasks of such planning system for construction production, the leading place is taken by the tasks of distribution and efficient use of all types of resources financial, labor, technical, material, natural. As a rule, the resources of a construction organization are always practically limited and therefore, to achieve such tasks, the achievements of scientific and technological progress and best construction practices are used to the maximum. Among the methods for solving them, methods of program-target planning and multi-criteria optimization, simulation modeling and financial management, a variety of marketing methods, etc are used. [3].

\section{Results and discussion}

A typical planning task is the determination of capital investments for the development of the means of production for the planning period by the construction organization. It is advisable to link the solution of problems of this class with the indicator of finished end-use construction products, for example, with the commissioning of living space. In this case, we can talk about replenishing obsolete equipment (building structures), increasing its volume and various combinations between them. Means of production are considered in the form of two groups means of labor (machinery, equipment) and objects of labor (materials, designs). The connection between the indicators of finished construction products and means of production is fundamental, since labor resources, using means of labor, affect objects of labor and as a result the arising production process creates finished construction products. This relationship can be represented as [1]

$$
f=a x_{i}+b x_{i}^{\prime}+c y_{i}+\mathrm{d} y_{i}^{\prime}
$$

Where $f$ is the cost of the construction of the building;

$a$ is a specific indicator of costs per $\mathrm{m} 2$ of area;

$b$ is a unit costs per unit of production of its own construction industry;

$c$ is a unit costs for the acquisition of means of labor;

$d$ is a specific indicator of the cost of acquiring materials and structures that are not manufactured by their own building industry; 
$x_{i}$ is the total area commissioned in $i$-period of time;

$y_{i}$ is a part of the commissioned area, the realized price of which is used to purchase capital goods.

Suppose, for example, that there is a certain ratio between capital investments in the development of its own construction industry and the cost of purchased materials and structures, which can be expressed as

$$
b x_{i}^{\prime}=g \cdot d \cdot y_{i}^{\prime}
$$

Where $g$ is an indicator of the ratio of capital investments in the development of its own building industry to the cost of purchased materials and structures.

Since we are talking about planning the distribution of financial resources for the acquisition of capital goods, expression (1) should be represented as

$$
f=a x_{i}+b\left(x_{i+1}-x_{i}\right)+c \cdot y_{i}+d\left(y_{i+1}-y_{i}\right)
$$

and the formula (2) in the form of

$$
b\left(x_{i+1}-x_{i}\right)=g d\left(y_{i+1}-y_{i}\right)
$$

As a result, we can get the following equation

$$
f=a x_{i}+b\left(x_{i+1}-x_{i}\right)+c y_{i}+\frac{b}{g}\left(x_{i+1}-x_{i}\right)
$$

Next, let's change the period $i=i+1$, then we will get

$$
f=a x_{i+1}+b\left(x_{i+2}-x_{i+1}\right)+c y_{i+1}+\frac{b}{g}\left(x_{i+2}-x_{i+1}\right)
$$

Let's subtract equation (5) from this equation. The resulting equation will be as follows

$$
b\left(\frac{g+1}{g}\right) x_{i+2}+\left[a-2 b\left(\frac{g+1}{g}\right)+\frac{b c}{d \cdot g}\right] x_{i+1}+\left[b\left(\frac{g+1}{g}\right)-a-\frac{b c}{d g}\right] x_{i}=0
$$

After conversion, this equation takes the following form

$$
x_{i+2}-\left[2-\frac{a d g+b c}{b d(g+1)}\right] x_{i+1}+\left[1-\frac{a d g+b c}{b d(g+1)}\right] x_{i}=0
$$

The resulting equation is a homogeneous linear equation in finite differences. In particular, if we designate $\frac{a d g+b c}{b d(g+1)}=h$, then

$$
x_{i+2}=(2-h) x_{i+1}+(1-h) x_{i}=0
$$

This means that this equation can be represented as a characteristic equation in the form of

$$
\tau^{2}-(2-h) \tau+(1-h) x_{i}=0
$$

and its solution is described in works $[2,6]$.

As the final result, the solution of the determinates will be;

$$
\begin{aligned}
x_{i} & =\frac{1}{a d g+b c}\left[d g f+b c x_{0}-c d g y_{0}-d g\left(a x_{0}-f+c y_{0}\right) \cdot(1-h)^{i}\right] \\
y_{i} & \left.=\frac{1}{a d g+b c}\left[b f-a b x_{0}+a d g y_{0}+b\left(a x_{0}-f+c y_{0}\right)\right) \cdot(1-h)^{i}\right]
\end{aligned}
$$


It should be noted that $x_{i=x_{0}}$ and $y_{i=y_{0}}$ if $i=0$, i.e. they represent the initial data.

\section{Conclusion}

By now planning is the most important function in the activities of contracting construction organizations, which makes it possible to objectively and reasonably develop a sustainable development strategy with the allocation of relevant priorities, to forecast real sales volumes of construction products and to create step-by-step tactics for increasing equity capital.

The planning system for construction production, which includes four interconnected levels of planning - general, strategic, current and operational, is the most rational for the conditions of development of market relations. In this case, the whole range of tasks of the activities of the construction organization is considered from the formation of a package of general ideas for forecast development to the daily implementation of the scope of work.

The urgent tasks of the planning system are the tasks of efficient distribution of all types of resources - financial, labor, technical, material, natural for construction projects and time periods. To solve these problems, various methods of multicriteria and system optimization, simulation modeling, risk analysis methods, and man-machine methods are used. However, the lack of information and the subjectivity of particular criteria lead to a large scatter of decisions. In this regard, it is advisable for the indicated class of problems to use methods for solving linear equations in finite differences that more accurately describe economic parameters and their relationship.

\section{References}

1. D.D. Anisimov-Spiridonov, Methods and models of large systems of optimal planning and management (Publishing house "Nauka", Moscow, 1969)

2. A.O. Gelfond, Calculus of finite differences. State publishing house of physical and mathematical literature (1959)

3. A.A. Zarenkov, Problems of development of construction companies in the Russian economy (Stroyizdat, St. Petersburg, 1999)

4. L.V. Kievsky, Planning and organizing the construction of utilities (Publishing house SvR-ARGUS, Moscow, 2008)

5. P.P. Oleinik, Organization, planning and management in construction. $2^{\text {nd }}$ edition, revised (Publishing House ACB, Moscow, 2017)

6. A.K. Scriabin, V.K. Durkin, The use of equations in finite differences in dynamic planning problems. - "Economic and mathematical methods" (Publishing House "Nauka", Moscow, 1965)

7. A.Y. Yurgaitis, P.P. Oleynik, Materials of the international scientific and practical conference "Project Management: Ideas, Values, Solutions", SPbGASU, 39-44 (2019)

8. P. Oleinik, A. Yurgaytis, MATEC Web of Conferences 117, 00130 (2017) https://doi.org/10.1051/matecconf/201711700130

9. P. Oleinik, A. Yurgaytis, MATEC Web of Conferences 193, 05010 (2018) https://doi.org/10.1051/matecconf/201819305010 